Saint Louis University School of Law

Scholarship Commons

All Faculty Scholarship

2004

Disentitlement? The Threats Facing Our Public Health-Care Programs and a Rights Based Response

Sidney D. Watson

Saint Louis University School of Law

Follow this and additional works at: https://scholarship.law.slu.edu/faculty

Part of the Health Law and Policy Commons

Recommended Citation

Sidney D. Watson (2004) DISENTITLEMENT? THE THREATS FACING OUR PUBLIC HEALTH-CARE PROGRAMS AND A RIGHTS-BASED RESPONSE, The Journal of Legal Medicine, 25:1, 111-117, DOI: 10.1080/01947640490401957

This Book Review is brought to you for free and open access by Scholarship Commons. It has been accepted for inclusion in All Faculty Scholarship by an authorized administrator of Scholarship Commons. For more information, please contact erika.cohn@slu.edu, ingah.daviscrawford@slu.edu. 


\section{DISENTITLEMENT? THE THREATS FACING OUR PUBLIC HEALTH-CARE PROGRAMS AND A RIGHTS- BASED RESPONSE}

\section{Sidney D. Watson}

To cite this article: Sidney D. Watson (2004) DISENTITLEMENT? THE THREATS FACING OUR PUBLIC HEALTH-CARE PROGRAMS AND A RIGHTS-BASED RESPONSE, The Journal of Legal Medicine, 25:1, 111-117, DOI: 10.1080/01947640490401957

To link to this article: https://doi.org/10.1080/01947640490401957

曲 Published online: 11 Aug 2010.

Submit your article to this journal $\widetilde{ }$

Џ Article views: 17 
The Journal of Legal Medicine, 25:111-117

Copyright $\odot 2004$ Taylor \& Francis

$0194-7648 / 04 \$ 12.00+.00$

DOI: $10.1080 / 01947640490401957$

\section{Disentitlement? The Threats Facing Our Public Health-Care Programs and a Rights-Based Response}

Tiмотнy Stoltzfus Jost (Oxford University Press, New York, 2003), 291 pages, $\$ 45$.

Reviewed by Sidney D. Watson, J.D., St. Louis, Missouri. ${ }^{*}$

\section{INTRODUCTION}

In the battle over the future of American health policy, the lines are drawn. On one side are those who seek to turn health care financing and delivery over to private markets that are individualized-where patients strike their own bargains rather than relying on employers or government insurers-and free from governmental mandates. On the other side are those who support a continuing role for government in assuring access to health insurance and health services and in controlling costs and monitoring the quality of care. The lines are hard, fast, and ideological.

The most recent skirmish ended November 24, 2003, when Congress finally passed a bill adding a prescription drug benefit to the Medicare program. The prescription drug debate became the latest cover for the ideological battle-should Medicare continue as a government insurance program with a defined benefit package or become a premium support program in which the federal government provides each beneficiary with a set sum of money to purchase fee-for-service care or a private insurance policy, HMO, or PPO plan?

In his latest book, Disentitlement? The Threats Facing Our Public Health-Care Programs and a Rights-Based Response, Professor Timothy Jost joins the ranks of those opposed to attempts to move American health care policy toward individualized, private markets. Published prior to the latest clash over Medicare, the book predicts the ideological debate and the philosophical divide. But where others describe the controversy from positions grounded in economics, distributive justice, utilitarian ethics, and public health, Disentitlement focuses on the role that law, legal rights, and courts play in forming and sustaining health systems.

\footnotetext{
* Professor of Law, Center for Health Law Studies, St. Louis University School of Law. Address correspondence to Professor Watson at 3700 Lindell Blvd., St. Louis, Missouri, 63110 or via e-mail at sdwatson@aol.com.
} 
Although the United States, unlike other developed countries, has no universal entitlement to health insurance or health care, more modest legal rights run through our health care financing and delivery system. Certain people are entitled to public health insurance through Medicaid and Medicare and, thus, have a right to a specified benefit package. Employees with employerprovided health insurance have a right to the benefits specified by their plan. Employers who offer health insurance can claim a tax deduction for the cost of their employees' health insurance. Health care providers have a right to be paid for services.

Disentitlement explores the nature and function of these legal entitlements to health care. The book's underlying thesis is that legal entitlements to health insurance and health care are essential; a private individualized market in health insurance cannot guarantee access to health insurance or health care. Moreover, the structure of entitlements affects the political acceptability and long-term viability of a nation's health care financing and delivery systems. ${ }^{1}$

Author Timothy Stoltzfus Jost is the Robert L. Willett Family Professor of Law at Washington and Lee School of Law, a prodigious scholar, and eminently qualified to hold forth on the subjects in Disentitlement. He has researched and written extensively about Medicare, Medicaid, managed care, and American health care reform. ${ }^{2}$ His scholarship spans the gamut of health law concerns - access, cost control, and quality of care ${ }^{3}$ - and includes a substantial body of comparative health law work. ${ }^{4}$ In this latest book, Jost draws on his encyclopedic knowledge of health care financing and delivery and the

\footnotetext{
${ }^{1}$ Timothy S. Jost, Disentitlement? The Threats Facing Our Public Health-Care Programs and a RightsBASEd RESPONSE viii (2003).

${ }^{2}$ See, e.g., Timothy Jost, The Tenuous Nature of the Medicaid Entitlement, 22 HeALth 145 (2003); Timothy Jost, Case Study: Pegram v. Herdrich: The Supreme Court Confronts Managed Care, 1 Yale J. Health PoL'y \& Eтнісs 187 (2001); Timothy Jost, Governing Medicare, 51 Ad. L. Rev. 39 (1999); Timothy Jost, American Health Law and Policy in the Wake of the Clinton Plan, 11 ZeITSCHRIFT FUR Auslandisches Und Internationales Arbeits Sozialrecht 123 (1997); Timothy Jost, Waiting for Reform, 26 J.L., Med. \& Eтнісs 63 (1994).

${ }^{3}$ See, e.g., Timothy Jost, Legal Issues in Quality of Care Oversight in the United States: Recent Developments, 10 E. J. Health L. 11 (2003); Timothy Jost, The American Difference in Health Care Costs: Is There a Problem? Is Medical Necessity the Solution?, 43 St. Lous U.L.J. 1 (1999); Timothy Jost, Administrative Adjudication Issues in Health Reform, 47 AD. L. REv. 425 (1995); Timothy Jost, Oversight of the Quality of Medical Care: Regulation, Managed Care or the Market?, 37 ArIz. L. Rev. 825 (1995); Timothy Jost, Health System Reform: Forward or Backward with Quality Oversight?, 271 J.A.M.A. 1508 (1994); Timothy Jost \& Sandra Tanenbaum, Selling Cost Containment, 19 Am. J.L. \& Med. 95 (1993); Timothy Jost, Policing Cost Containment, 3 Puget Sound L. Rev. 483 (1991).

${ }^{4}$ See, e.g., Timothy Jost, Private or Public Approaches to Insuring the Uninsured: Lessons from International Experience with Private Insurance, 76 N.Y.U. L. Rev. 419 (2001); Timothy Jost, Managed Care Regulation: Can We Learn from Others? The Chilean Experience, 32 Mich. J.L. Reform 863 (1999); Timothy Jost, Health Care Rationing in the Courts: A Comparative Study, 21 Hastings Int'L \& Comp. L. Rev. 639 (1998); Timothy Jost, German Health Care Reform, the Next Steps, 23 J. Health Pol., PoL'y \& L. 697 (1998); Timothy Jost, The British Health Care Reforms, The American Health Care Revolutions, and Purchaser/Provider Contracts, 20 J. Health Pol., Pol'y \& L. 885 (1996); Readings in Comparative Health Law and Bioethics (Timothy Jost ed. 2001).
} 
role of law ${ }^{5}$ to compare public and private insurance programs and American and European health care systems.

As Disentitlement's subtitle-The Threats Facing Our Public HealthCare Programs and a Rights-Based Response-suggests, the book undertakes two interlocking projects. The first endeavor is an exploration of the need for and nature of legal rights to health insurance and health care. The second, much shorter, undertaking is Jost's proposal for a rights-based health care financing and delivery system in which United States health care entitlements are recast into a social insurance system funded by multiple sources but with heavy reliance on payroll taxes. ${ }^{6}$ The details of this rights-based response rush by in a dizzying 14-page blur. One wishes for another book in which Jost can develop more fully the details and intricacies of his social insurance proposal, but Disentitlement's first 264 pages offer a rich and nuanced examination of how law and courts structure health care systems.

The book offers a variety of frameworks for analyzing the origins, forms, and structures of legal rights to health care. Chapters two through ten are devoted to this inquiry and can be divided into four parts: the case for health care entitlements; the history and character of American health care entitlements; the threats to health care entitlements; and health care entitlements in Great Britain and Germany. Jost explores not only the legal structure and history of health care entitlements in the United States but also the structure and history of two prominent alternative foreign models - the general-revenue-tax-based National Health Service of the United Kingdom and the social insurance program of Germany.

\section{PART 1: THE CASE FOR HEALTH CARE ENTITLEMENTS}

Jost's main proposition, set forth in this first segment, is straightforward and unequivocal: a legal entitlement to health insurance is necessary because a private, individual market cannot achieve universal access to affordable health insurance. Laying a foundation for this assertion, chapter two offers a lucid, easily accessible introduction to the concepts of insurance, risk rating, and risk pooling, and explains why attempts to promote individual health insurance to expand access to health care are doomed to failure. This chapter would make excellent reading for any health law or policy course that addresses issues of insurance.

Jost uses automobile insurance, for a lordly Bentley and a low end Kia, to illustrate how health insurance differs from other forms of insurance. Outside

\footnotetext{
${ }^{5}$ Jost is also a co-author of one of the foremost health law casebooks, BARRY FURrow ET AL., HEALTH LAW: Cases, Materials and Problems (4th ed. 2001), as well as a related health law treatise and hornbook. See also The Law of Medicare and Medicaid Fraud and Abuse (Timothy Jost \& Sharon Davis eds. 2002); Regulation of the Health Care Professions (Timothy Jost ed. 1997).

${ }^{6}$ Jost, supra note 1, 265-79.
} 
of the health insurance context, the cost of insurance is correlated with the cost of the insured item and the likelihood of loss. It costs more to insure a Bentley than a Kia, and more to insure a careless driver than a careful one. The costs of insurance are factored into the decision to purchase; thus, in deciding whether to buy a Bentley or a Kia, one considers not only the purchase price of the vehicle, but also the costs of insuring each. Those with greater wealth generally purchase higher-priced items and, typically, carry higher-cost insurance. Those with lesser wealth can go without insurance.

By contrast, health insurance costs are not tied to wealth but to health status, and the need for health services is remarkably skewed. Jost presents the classic graph showing annual health care expenditures by population: $1 \%$ of the population accounts for $27 \%$ of health care costs; $10 \%$ of the population accounts for nearly $70 \%$ of all health care expenditures; and $50 \%$ of the population accounts for only $3 \%$ of health care expenditures. ${ }^{7}$ In an individualized private insurance market, rates vary not based upon wealth but upon expected health care needs and utilization. Because poorer people often have poorer health status, the $10 \%$ of the population who most need health care may not have the wealth to purchase it or to secure individual health insurance. An entitlement to group health insurance-either through public health programs such as Medicaid or Medicare or through private, employer-provided policies_-is a necessary response to this market failure.

\section{PART 2: THE HISTORY AND CHARACTER OF AMERICAN HEALTH CARE ENTITLEMENTS}

Chapters three and four explore the history and character of legal rights to Medicare, Medicaid, and employer group coverage. These chapters offer newcomers to health law and policy a thorough overview of legal rights to these forms of coverage and provide more seasoned health law aficionados with a nuanced analysis of the contrasts among rights in these three fundamental —and, in some respects, fundamentally different - types of programs. This section contains an abundance of information, both in the text and the footnotes.

Chapter three is a cornucopia of legal doctrine including constitutional theory, statutory and administrative law, and tax policy. Jost traces the rise and fall of efforts to establish a positive right to health care in the United States Constitution. He pinpoints the statutory language in Medicare and Medicaid that creates legal entitlements, contrasting this language with the lack of any statutory entitlement to employer-based group health insurance. ${ }^{8}$

\footnotetext{
${ }^{7}$ Id. at 8-9 (citing Marc L. Berk \& Alan C. Monheit, The Concentration of Health Care Expenditures Revisited, 20 Health Afr. 9, 12 (Mar.-Apr. 2001)).

${ }^{8}$ The Internal Revenue Code entitles employers and employees to favored tax treatment if an employer chooses to offer health insurance but does not require that employers offer health insurance.
} 
He then compares and contrasts entitlements to eligibility, benefits, provider participation, reimbursement levels, and judicial review in the three different contexts. Jost concludes by examining how legal entitlements to health care get entangled with government budget battles and the process by which legal entitlements become political entitlements.

Chapter four looks at the historical foundations of American health care entitlements. It traces the origins of health care for the poor from the charity of Elizabethan poor laws and the asylum movement to the beginnings of entitlements to care found in Civil War veterans' pension programs and the emergence of social insurance in Europe. Jost traces the ebb and flow of efforts to create entitlements to health insurance and health care in twentieth-century America, exploring the politics and rights language of the New Deal, tax-subsidized, employer-provided health insurance, Medicare, Medicaid, ERISA, and the various efforts to enact some form of universal social health insurance. The chapter is wide-ranging and comprehensive, an excellent introduction for those new to the health care field. Even for those generally familiar with this subject matter, Jost's exposition enhances understanding and reveals details not previously known.

\section{PART 3: THREATS TO AMERICAN HEALTH CARE ENTITLEMENTS}

Chapters five through eight offer a concise history of recent experiments with market-based reforms in both the public and private sectors. In them, Jost sets out the theories and facts that underlie market-based proposals, while exposing their failure to assure universal access to health insurance and health care. He identifies three major threats to America's public health-care programs - privatization, devolution, and individualization - that jeopardize legal rights to Medicare, Medicaid, and employer-based group insurance. Privatization is the push for private administration of public programs, exemplified by Medicare and Medicaid managed care and, some might argue, by the recently passed package of Medicare changes. Devolution seeks to move authority over public health care programs from the federal to state governments, resulting in less federal control, more state autonomy, and fewer entitlements for beneficiaries and providers. Individualization aspires to replace group health insurance with individual choice.

Proponents of privatization, devolution, and individualization seek to transform Medicare from group health insurance with a defined benefit package into a voucher, premium support, or investment account system in which individuals would receive a set amount of money to purchase individual health insurance policies or medical services. They also seek to repeal tax subsidies for employment-based health insurance in order to move private insurance out of employer groups and into the individual market. 
After explaining the theory and principles that underlie these, and other, efforts to privatize, devolve, and individualize health insurance, Jost examines the successes and failures of various reform initiatives, including Medicaid and Medicare managed care. He concludes that these privatized, individualized initiatives offer little hope of increasing access, reducing cost, or improving quality. They do, though, threaten to destroy existing rights to health insurance and health care for those who do not have the health and wealth to secure adequate care in a market system.

\section{PART 4: HEALTH CARE ENTITLEMENTS IN GREAT BRITAIN AND GERMANY}

In Part 4, Jost describes the legal character of health care entitlements in other developed nations, exploring the two dominant models of public health insurance - general-revenue-funded national health insurance and social insurance. Chapter nine examines the British National Health Service (NHS) as the prototype for the former; chapter ten uses the German social insurance system as a model for the latter.

The key difference between national health insurance and social insurance is the source of financing. National health insurance systems, like Britain's NHS, are funded primarily from general tax revenues. Social insurance systems, like Germany's, are financed primarily through payroll taxes from employers and employees. ${ }^{9}$ Jost examines how these funding differences affect the gamut of health care legal entitlements: eligibility; benefits; provider participation; cost control; and judicial review of disputes over coverage. His exposition of the British and German experiences provides an interesting and useful reference point from which to project how the American system might be reformed.

\section{THE LESSONS}

Ultimately, the heart of Jost's wide-ranging analysis of health care entitlements lies in two key lessons about how legal rights support efforts to create sustainable systems that offer accessible and affordable health care. The first lesson is that a private market in individual health insurance will not, and cannot, assure access to health insurance. The need for health care is not like other insurable risks. Since the need for care is based on health, not wealth, those most likely to need coverage - the elderly and those with chronic illness-are least likely to be able to afford risk-rated health insurance. While intensive government regulation might transform a free market

\footnotetext{
${ }^{9}$ The British system collects about $12 \%$ of its funding from a payroll tax that is a holdover from pre-NHS days. The German system uses general tax revenues to cover those who are not in the workforce.
} 
in health insurance into a regulated market in health insurance, the administrative costs associated with individual health insurance make it exorbitantly expensive when compared with group-based alternatives.

The second lesson is that the conceptual basis for legal entitlements to health care plays a crucial role in the long-term viability of health care financing and delivery systems. Social insurance entitlements produce the most politically sustainable entitlements to health care. Health care entitlements that arise from general tax revenue programs, such as Medicaid and Britain's NHS, are politically unstable. When eligibility is overly restrictive, as is typically the case with Medicaid, recipients do not have the political power to protect the program. Even when general-revenue-funded health programs have broad-based eligibility, as in Great Britain, they inevitably become entangled in broader government budget battles. Their budgets wax and wane as the economy fluctuates and other governmental needs and programs vie for limited funds.

An insurance model - whether private insurance or social insurancecreates the most sustainable form of health care entitlements because it is based on an exchange relationship. The insured pays a premium, contribution, or payroll tax and, in return, receives health care coverage when the need for services arises. This exchange relationship not only allows for the pooling of risk but also creates political and legal entitlements. Both Medicare and Germany's public health system have proven to be politically stable because workers and employers who pay a dedicated payroll tax demand a fair return from their social insurance system. Having a program funded by dedicated contributions, obtained through a payroll deduction or other premium-paying mechanism, also assures that the health insurance pool is protected from other governmental demands on the funds.

\section{CONCLUSION}

Disentitlement? The Threats Facing Our Public Health-Care Programs and a Rights-Based Response is a timely and important book. As we continue to debate the future of Medicare, Medicaid, and employer-provided coverage, it reminds us of the role that law, legal entitlements, and courts play in structuring and maintaining health care financing and delivery systems. Efforts to privatize, devolve, and individualize health insurance may resonate with many lawmakers and members of the American public, particularly in these times of an uncertain economy and expanding government deficits; but Professor Jost's book reminds us that we need to carefully examine the premises and promises of these reform initiatives. Markets cannot and will not assure universal access to health insurance and health care. The only way to assure universal access is to create legal rights—in other words, an entitlement. 